\title{
SOIL SURFACE CHARACTERISTICS INFLUENCE ON INFILTRATION IN BLACK MARLS: APPLICATION TO THE SUPER-SAUZE EARTHFLOW (SOUTHERN ALPS, FRANCE)
}

\author{
JEAN-PHILIPPE MALET, ${ }^{1 *}$ ANNE-VERONIQUE AUZET,${ }^{1 \dagger}$ OLIVIER MAQUAIRE, ${ }^{1 \neq}$ BRUNO AMBROISE, ${ }^{\dagger}{ }^{\dagger}$ \\ LUC DESCROIX, ${ }^{2}$ MICHEL ESTEVES, ${ }^{2}$ JEAN-PIERRE VANDERVAERE ${ }^{2}$ AND EMMANUEL TRUCHET ${ }^{3}$ \\ ${ }^{1}$ Centre d'Études et de Recherches Éco-Géographiques (CEREG), FRE 2399 ULP-CNRS-ENGEES, 3, rue de l'Argonne, F-67083 \\ Strasbourg Cedex, France \\ ${ }^{2}$ Laboratoire d'Étude des Transferts en Hydrologie et Environnement, (LTHE), UMR 5564 CNRS-UJF-IRD-INPG, BP 53, F-3804I \\ Grenoble Cedex, France \\ ${ }^{3}$ Faculté de Géographie et d'Aménagement, Université Louis Pasteur, 3, rue de l'Argonne, F-67000 Strasbourg, France
}

Received 24 August 2001; Revised 28 August 2002; Accepted 7 October 2002

\begin{abstract}
Soil surface characteristics (SSCs) have a strong influence on the infiltration properties at the soil surface. They can explain spatial variations in the infiltration processes observed under natural rainfall for relatively little-differentiated material and can help us to understand the surface and subsurface hydrology of landslides, representative of some of black marls landscapes of the French southern Alps. This paper presents the results of investigations into the influence of SSCs using careful morphological description, in situ tension-disc infiltrometry and statistical analysis (hierarchical ascending classification and stepwise discriminant analysis). The site studied is the Super-Sauze earthflow. The selected infiltration and runoff variables were described for 233 microplots chosen all over the earthflow. The results show that an approach based on a description of relevant variables influencing water infiltration can validate a typology based on 'expert' knowledge. Hydraulic conductivity at saturation was measured on 36 undisturbed soil cores and at low negative pressure heads on 83 microplots: the dispersion exceeds three orders of magnitude at each pressure head. A statistical analysis of the data set obtained by describing selected variables showed the relevance of the black marl descriptors when defining types of SSC that enable us to distinguish significant hydrodynamical behaviour. This leads us to suggest a distribution of hydraulic conductivity curves near saturation for each SSC type, which can be used as a key to distribute local hydraulic conductivity values adapted to black marl hillslopes. As well as the types of SSC at a microplot scale leading to types of hydrodynamic properties, the typology of combinations of SSCs at a coarser scale should lead to types of hydrological response and to identification of hydrological and geomorphological response units. Copyright (c) 2003 John Wiley \& Sons, Ltd.
\end{abstract}

KEY WORDS: black marls; soil surface characteristics; hydraulic conductivity; tension-disk infiltrometry; earthflow; statistical analysis

\section{INTRODUCTION}

Soil surface characteristics (SSCs; e.g. crusting, vegetation, stone cover) strongly influence the infiltration properties at the soil surface, mainly through the geometry of the porous system and the micro-relief. The spatial variability and the dynamics of several SSCs lead to heterogeneous infiltration and runoff responses on hillslopes, which are important drivers in geomorphology. These influences are recognized (Casenave and Valentin, 1989; Poesen et al., 1990) and well documented, mainly for cultivated soils (Auzet et al., 1995, Auzet, 2000; Léonard and Andrieux, 1998; Wainwright, 1996). Attempts have been made to integrate them into hydrological and erosion modelling (Jetten et al., 1996; Le Bissonnais, 1998; Moussa et al., 2002). SSCs

\footnotetext{
* Correspondence to: J.-P. Malet, Institut de Physique du Globe de Strasbourg (IPGS), UMR 7516 ULP-CNRS, 5, rue René Descartes, F-67084 Strasbourg Cedex, France.

$\dagger$ Present address: Institut de Mécanique des Fluides et des Solides (IMFS), UMR 7507 ULP-CNRS, 2, rue Boussingault, F-67000 Strasbourg, France.

‡ Present address: Institut de Physique du Globe de Strasbourg (IPGS), UMR 7516 ULP-CNRS, 5, rue René Descartes, F-67084 Strasbourg Cedex, France.
} 
are, nevertheless, poorly taken into account in the modelling of uncultivated mountainous landscapes, such as black marl, which is one of the most common outcrops in the Alpine massif. Black marls are subject to intense weathering, mass movements and gullying, and it is essential to define the regolith's infiltration properties in order to assess them.

The monitoring of earthflow movement and hydric conditions on the Super-Sauze research hillslope (Barcelonnette basin, southern Alps, France) has shown that significant displacements of up to $0.4 \mathrm{~m} \mathrm{day}^{-1}$ (Malet et al., 2002a) were associated with the presence of high groundwater levels at a depth of 1 to $2 \mathrm{~m}$. This leads to questions about the infiltration contribution (by direct rainfall) to the increasing level of the ground water table, even if the hydraulic conductivity of the marly regolith is generally low considering the clay texture $\left(5.0 \times 10^{-6} \mathrm{~m} \mathrm{~s}^{-1}\right.$; Van Asch and Buma, 1997). Despite a relatively homogeneous soil texture and water content and the absence of vegetation, observations made under natural rainfall revealed large spatial differences in the distribution of water between infiltration and runoff at the soil surface, even during very wet periods. These differences appeared to be related to the main aspect of the soil surface: fairly smooth or not, crusted, etc. Patches with different SSCs can be roughly identified and mapped overall. This overall visual identification is referred to hereafter as the SSC 'expert' approach.

A series of experiments was carried out on the local and hillslope scales to explore the relationship between the SSCs and surface hydraulic conductivity in order to classify the spatial variations in the infiltration properties. The main purposes of the first step reported in this paper are (i) to validate the 'expert' identification of SSC types by describing variables that could influence infiltration and (ii) on a local scale, to see if the SSC typology could be regarded as a hydraulic conductivity typology, using detailed SSC descriptions and in situ tension-disc infiltrometry measurements.

\section{STUDY AREA}

The Super-Sauze earthflow (Alpes-de-Haute-Provence, France) lies in an enclosed marly torrential basin gullied in badlands (Figure 1). The research hillslope was selected as representative of reworked landscapes in the Barcelonnette basin. Since 1990 it has been investigated and equipped to characterize the earthflow dynamics in relation to climatic and hydrologic conditions.

Altitudes range from $2105 \mathrm{~m}$ at the crown, which is cut into in situ black marls covered by morainal deposits, and $1740 \mathrm{~m}$ at the toe of the earthflow. The earthflow itself covers $17 \mathrm{ha}$ and has an average slope of $25^{\circ}$. Geotechnical investigations of in-depth displacements by inclinometers (Flageollet et al., 2000) and geophysical prospecting (Schmutz et al., 2000) indicate that the heterogeneous earthflow has a maximum depth of $20 \mathrm{~m}$ and fossilizes an intact palaeotopography formed by a succession of in situ Callovo-Oxfordian black marl crests and gullies. The surface is affected by rills and there are two deeply incised lateral gullies (Maquaire et al., 2001).

The palaeotopography strongly influences the behaviour of the flow by delimiting compartments with different characteristics and creating preferential water and sediment pathways. The earthflow comprises reworked blocks and panels of marls at various stages of weathering, clasts of all sizes, a silty-clayed matrix $\left(d_{10}=0.4 \mu \mathrm{m} ; d_{50}=500 \mu \mathrm{m}\right)$, and some morainic blocks. The marl blocks disintegrate into plates, spangles or elongated chips under the action of meteoric agents (mainly cryoclastism), depending on possible schistosity and lineation combinations, their clay and carbonate contents, their porosity and microstructures (Antoine et al., 1995; Descroix and Olivry, 2002). The final stage of weathering leads to the formation of silts and clays. The earthflow material is affected by cracking due to mechanical tension or desiccation. Vegetation is limited to patches in a very few locations. Mediterranean mountainous climatic conditions result in highly variable rainfall (400 to $1300 \mathrm{~mm}_{\text {year }}{ }^{-1}$ ), intense summer and autumn storms, which can reach intensities of $50 \mathrm{~mm} \mathrm{~h}^{-1}$ in $15 \mathrm{~min}$, snow cover and freezing for 130 days per year on average.

\section{SOIL SURFACE CHARACTERISTICS}

The SSCs of the hillslope are heterogeneous and strongly influenced by weathering and seasonal factors, even on a local scale. The main differences are due to the presence of marl blocks and boulders, weathered or 


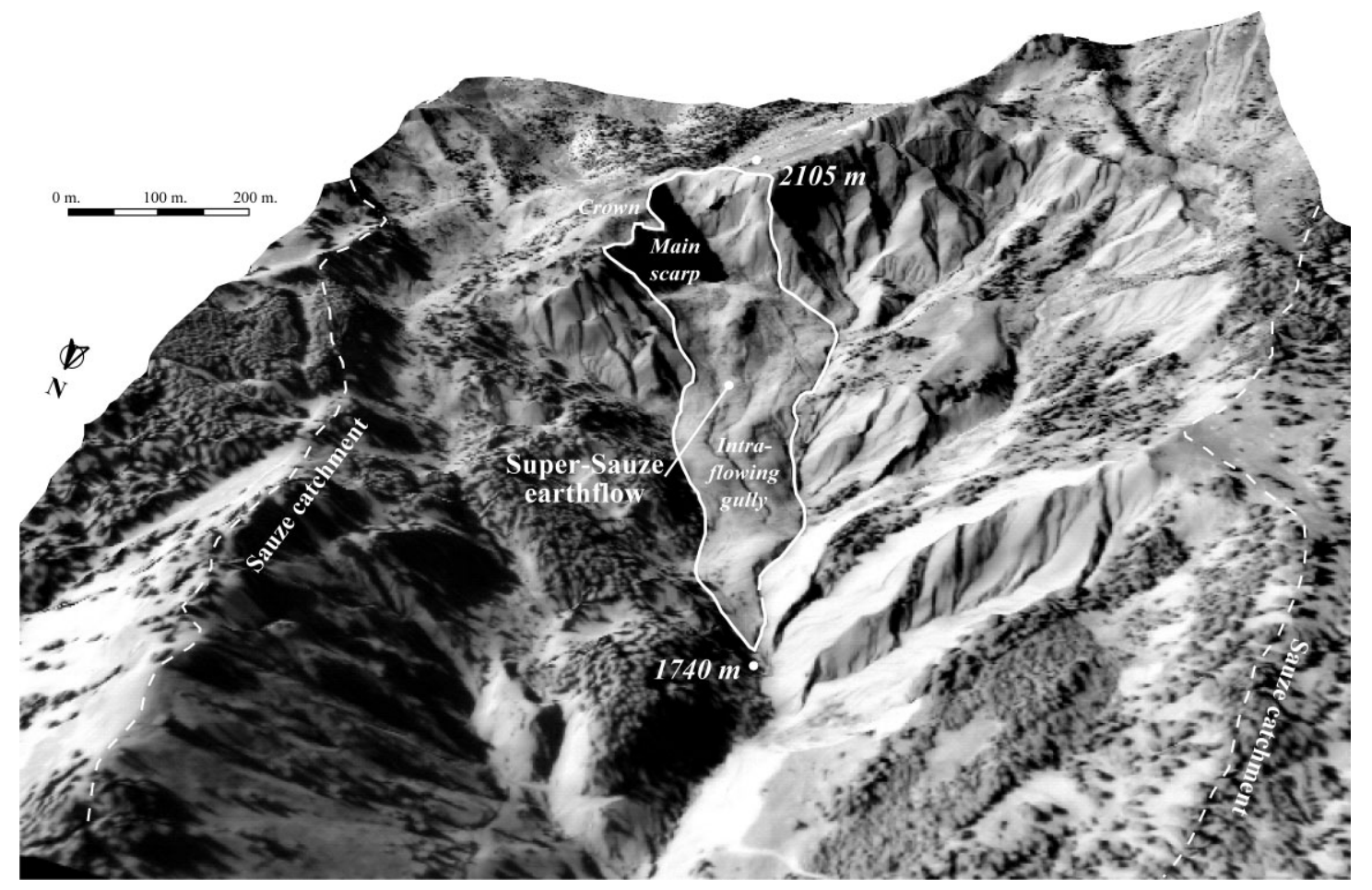

Figure 1. Morphology of the Super-Sauze catchment

not, and to crusting. Six types of SSC related to the aspect were identified visually by an expert approach, according to the decreasing proportion of coarse fragments, the extent to which they were sealed and the types of crust (Figure 2a to f).

Type 1 (BB) covers areas with in situ marl blocks and boulders, as yet unweathered or little weathered (Figure 2a). Sizes vary from $0.2 \mathrm{~m}$ (boulder) to $4 \mathrm{~m}$ (marl blocks and panels). No crust is observed. Sub-types can be distinguished by comparing the direction of the schistosity with the topographic surface (BB1 presents schistosity more or less parallel to the surface, $0-15^{\circ}$; BB2 presents schistosity dipping from 15 to $90^{\circ}$ ).

Type 2 (UCL) covers areas with a high proportion of assembled unsealed clasts (Figure $2 \mathrm{~b}$ ) of various shapes and sizes ( 0.01 to $0.2 \mathrm{~m}$ ), caused by type 1 weathering. The dipping and packing of clasts may vary and two sub-types can be distinguished, depending on the assemblage direction. UCL1 presents clasts piled up parallel to the topographic surface and UCL2 presents clasts dipping from 15 to $90^{\circ}$.

Type 3 (SCL) groups areas with highly weathered sealed clasts (Figure 2c), completely encased in a fine matrix. In this type, no particular dipping of the clasts can be distinguished.

Type 4 (GC) corresponds to gravel crust with more than $60 \%$ of coarse fragments ( $\geq 2 \mathrm{~mm}$; Figure $2 \mathrm{~d}$ ) and it appeared on debris flow deposits. The coarse fragments are included in a crust 30 to $45 \mathrm{~mm}$ thick. The lower part of the crust is finer, without vesicular pores, and the top part is a coarse sandy crust. Few desiccation cracks $(0 \cdot 1-0.2 \mathrm{~cm}$ width and depth) can be observed. The size of the coarse fragments and the proportion of finer material vary greatly, and two sub-types can be distinguished: sub-type GC1, where the percentage of coarse fragments reaches $10-20 \%$ and the size of the coarser elements is $2-2.5 \mathrm{~cm}$, and sub-type GC2, where the percentage of coarse fragments reaches $20-30 \%$ and the size of the coarser elements is $3-5 \mathrm{~cm}$.

Type 5 (SC) corresponds to finer fragmented structural crust of sandy clay, 25 to $30 \mathrm{~mm}$ thick, including some clasts or calcite fragments, more or less disaggregated, which give a roughness of 0.2 to $0.5 \mathrm{~cm}$ (Figure 2e). This crust, formed by a single microhorizon, differs from the subjacent layer and presents many desiccation cracks (width $0 \cdot 1-0 \cdot 2 \mathrm{~cm}$, depth $1-2 \mathrm{~cm}$ ) but no vesicular porosity. 
Type 6 (DC) covers areas with depositional crusts with a clayey-silty texture at the surface and a thickness of 2.5-3.5 cm (Figure 2f). These compact layers cover areas of up to $50 \mathrm{~m}^{2}$, in depression zones located upslope of emergent blocks or near earthflow compression ridges. Polygonal cracks of 0.7 to $1.8 \mathrm{~cm}$ width and 0.5 to $3 \mathrm{~cm}$ depth are observed. The profile presents sorted microhorizons where coarser elements appear at the base, due to sedimentation. Two sub-types can be distinguished according to the size of the coarser element and the proportion of matrix $(<0.2 \mathrm{~cm})$, which covers at least $85 \%$ of the area: sub-type DC1, where the percentage of matrix reaches $85-90 \%$ and the size of the coarser elements is $0 \cdot 2-0 \cdot 3 \mathrm{~cm}$, and sub-type DC2, where the percentage of matrix reaches $90-100 \%$ and the size of the coarser elements is $0.05 \mathrm{~cm}$.

On the crusted surfaces (types 4 to 6), gypsum efflorescences often appear early in the summer. Crusts form quickly during and after rain, and may disappear quickly during long or intense rainfalls, when the earthflow surface takes on the consistency of a viscous very sticky mud.

\section{2a/ BB: Blocks and Boulders of marls non or little weathered.}
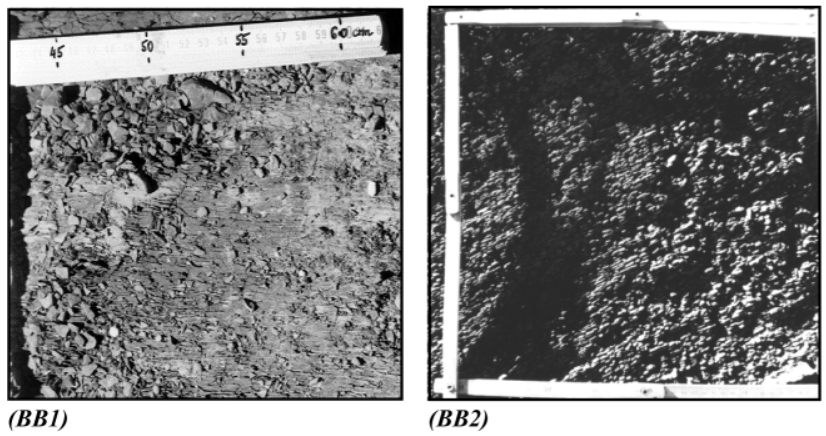

2b/UCL: marly blocks in a weathering process, Unsealed CLasts.
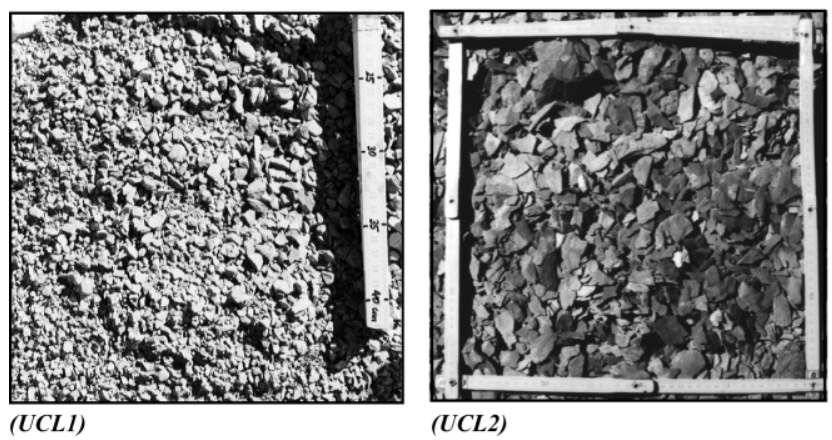

IN SURFACE

Marly clasts / Microtectonics

Moraine / Calcite fragments

Marly matrix (elements $<0.05 \mathrm{~mm}$ )

IN SUB-SURFACE

Reworked material or debris flow deposits

(UCL2)

2c/ SCL: marly block in a weathering process, Sealed CLasts.
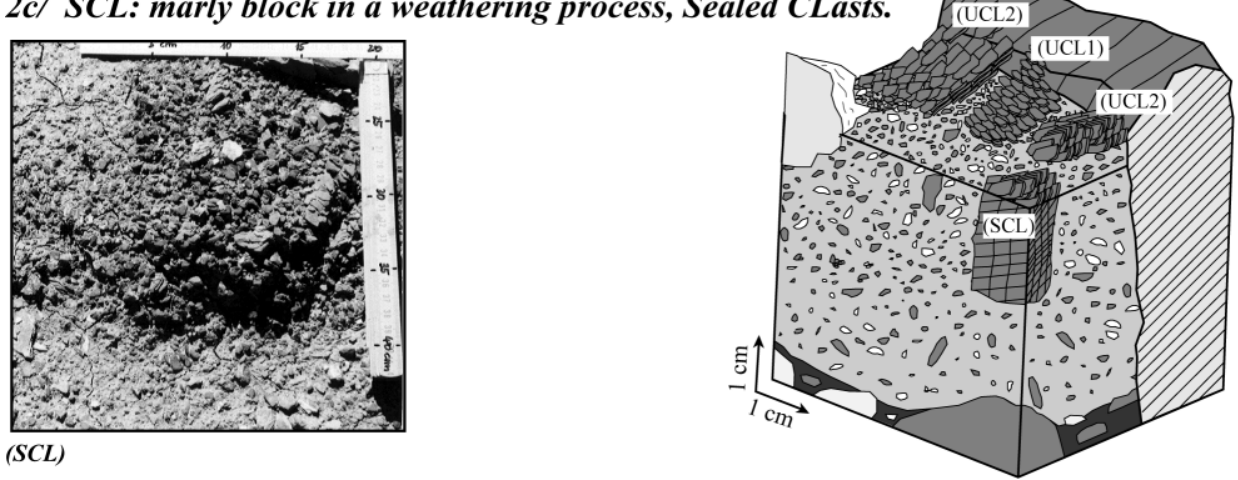

Figure 2. Morphology of the six types and ten sub-types of SSCs 
2d/GC: Gravel Crusts.
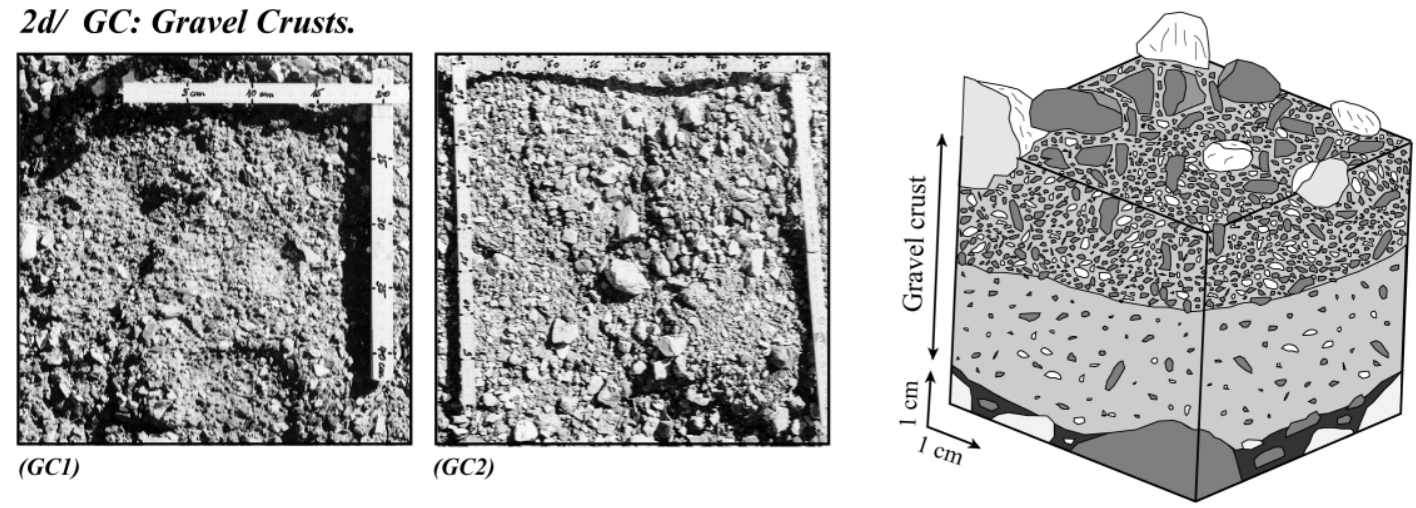

2e/ SC: Structural Crusts.
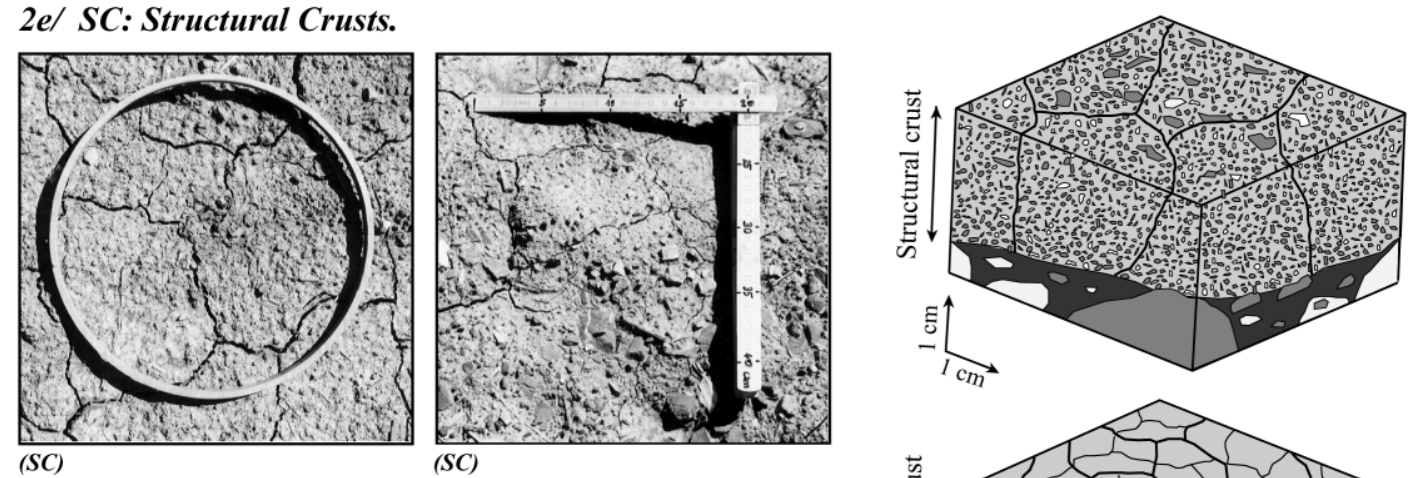

2f/ DC: Depositional Crusts.
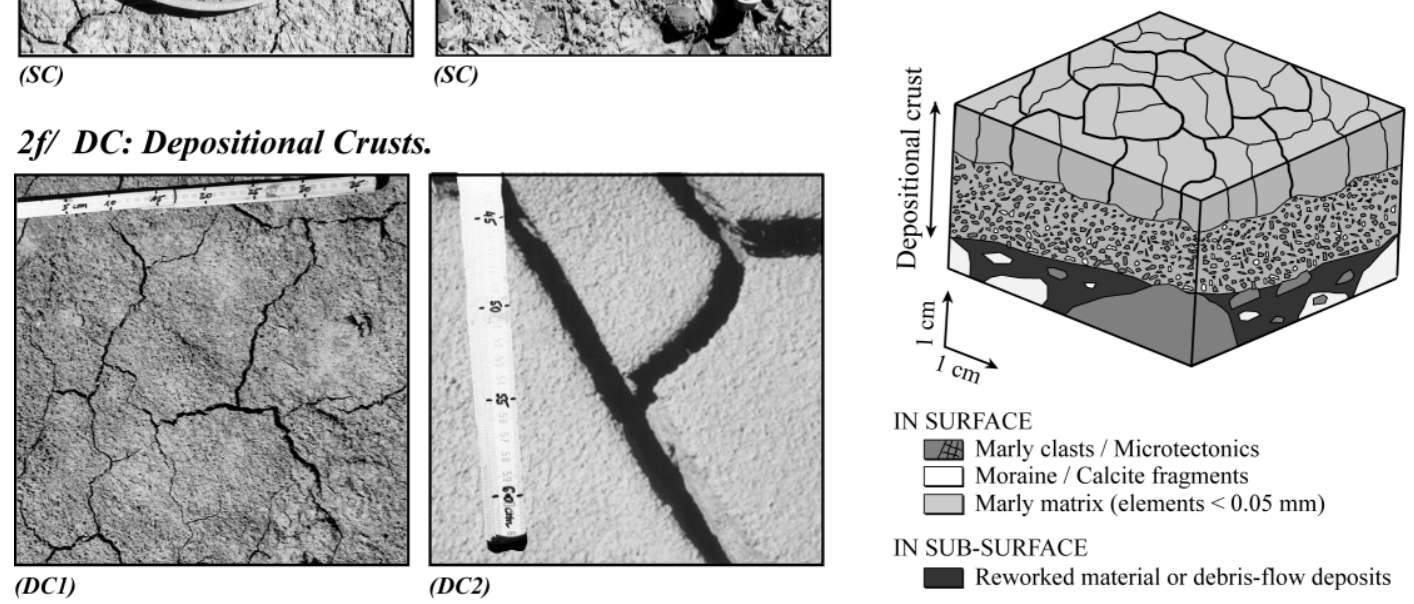

IN SURFACE

Marly clasts / Microtectonics

Moraine / Calcite fragments

$\square$ Marly matrix (elements $<0.05 \mathrm{~mm}$ )

IN SUB-SURFACE

Reworked material or debris-flow deposits

Figure 2. (Continued)

\section{MATERIALS AND METHODS}

The approach adopted aims at studying both SSCs and conductivities on a large sample of 233 microplots randomly selected in the several SSC types all over the earthflow, according to their relative proportions. The methodology is based on the use of:

- A selection of descriptors of the surface conditions, according to the knowledge of the main processes and factors involved in infiltration/runoff partition (Bradford et al., 1987; Casenave and Valentin, 1989; Abrahams and Parsons, 1991; Auzet, 2000).

- Tension-disc infiltrometry, which provides in situ conductivity in the low-suction domain (Smettem and Clothier, 1989; Angulo-Jaramillo et al., 2000) and can be used on crusted soils (Vandervaere et al., 1997). 
The low-suction domain is of interest since the dynamic response of this type of earthflow occurs in very wet conditions (Malet et al., 2002b).

- Statistical analysis, using hierarchical ascending classifications and stepwise discriminant analysis to analyse the descriptive data sets, to divide the 233 microplots into groups for comparison with the 'expert' typology and to identify the most discriminant variables.

\section{Description of soil surface characteristics and sampling strategy}

The SSC description was carried out on microplots $\left(0.1\right.$ to $\left.0.2 \mathrm{~m}^{2}\right)$, using an adapted version of the general description form proposed by Auzet (2000). This is focused on generally recognized factors influencing water infiltration and depressional storage:

- soil texture has a strong influence on structure and porosity, aggregate stability, detachment and crust formation dynamics;

- stones, which can promote or prevent infiltration, depending on their size and shape and their contact with the finer particles (sealed or not);

- microrelief and roughness influence depressional storage;

- density, size and distribution of macropores (including dessication or tension cracks) strongly influence infiltration at saturation;

- the clasts influence infiltration or runoff under natural rainfall, and their size and their direction relative to the soil surface are expected to be controlling variables. These are specific characteristics in the weathering of black marls.

The surface characteristics were described on each microplot through 12 descriptors adapted to the marly hillslope conditions (Table I). The percentage of covered area was estimated for each variable by visual observation and the roughness and size of the fragments were measured with a ruler. The density of cracks was estimated by measuring the length and width of the fissures on the microplots. In the description form, the variables of the class soil texture $([\geq 2 \mathrm{~cm}],[0 \cdot 2-2 \mathrm{~cm}],[<0 \cdot 2 \mathrm{~cm}])$, refer to the percentage of the area covered by debris elements, whatever their origin (marls, moraine, calcite, etc.); the three classes cover $100 \%$ of the microplot area. The variable [CL] refers to the area covered only by marly fragments, whatever their size. As no vegetation covers such types of landscape, it is not considered in the form. Modalities of the descriptors were defined a priori.

Table I. Descriptors of the SSCs

\begin{tabular}{|c|c|c|c|}
\hline & Name of variable & Variable & Unit/Modalities \\
\hline Soil & $\begin{array}{l}{[<0 \cdot 2 \mathrm{~cm}]} \\
{[0 \cdot 2-2 \mathrm{~cm}]} \\
{[\geq 2 \mathrm{~cm}]}\end{array}$ & $\begin{array}{l}\text { Finer material }<0.2 \mathrm{~cm} \\
\text { Fragments from } 0.2 \text { to } 2 \mathrm{~cm} \\
\text { Coarse fragments of size } \geq 2 \mathrm{~cm}\end{array}$ & $\begin{array}{l}{[\% \text { of the area }]} \\
{[\% \text { of the area }]} \\
{[\% \text { of the area }]} \\
\text { The total of the three equals } 100 \%\end{array}$ \\
\hline Stones & $\begin{array}{l}{[\mathrm{SCF}]} \\
{[\mathrm{SF}]}\end{array}$ & $\begin{array}{l}\text { Shape of the coarse fragments of size } \geq 2 \mathrm{~cm} \\
\text { Sealed fragments }\end{array}$ & $\begin{array}{l}\text { [angular, subangular] } \\
{[\% \text { of the area] }}\end{array}$ \\
\hline Roughness & [ROU] & Roughness in the runoff direction ${ }^{\mathrm{a}}$ & [median, in mm] \\
\hline Cracks & $\begin{array}{l}{[\mathrm{CR}]} \\
{[\mathrm{WCR}]} \\
{[\mathrm{DCR}]}\end{array}$ & $\begin{array}{l}\text { Cracks } \\
\text { Width of cracks } \\
\text { Depth of cracks }\end{array}$ & $\begin{array}{l}{\left[\mathrm{m} \mathrm{m}^{-2}\right]} \\
{[\text { median, in } \mathrm{mm}]} \\
\text { [median, in } \mathrm{mm}]\end{array}$ \\
\hline Clasts & $\begin{array}{l}{[\% \mathrm{CL}]} \\
{[\mathrm{ORI}]} \\
{[\mathrm{SIZ}]}\end{array}$ & $\begin{array}{l}\text { Marly coarse fragments } \\
\text { Dipping of clasts or schists } \\
\text { Size of the coarser clasts }\end{array}$ & $\begin{array}{l}{[\% \text { of the area }]} \\
{\left[0 ; 0-15^{\circ}, 15-90^{\circ}, \text { variable }\right]} \\
{[\mathrm{mm}]}\end{array}$ \\
\hline
\end{tabular}

\footnotetext{
${ }^{a}$ Median height of the small pass on the runoff bed.
} 


\section{INFLUENCE OF SOIL SURFACE CHARACTERISTICS ON INFILTRATION}

The number of classes (from three to eight according to the variable) was selected according to their possible distinction in the field or according to functional thresholds. Despite some subjectivity, plot descriptions made by different observers usually appeared to be very consistent.

\section{Tension-disc infiltrometry measurements}

The device follows the design by Perroux and White (1988), using a 250 or $80 \mathrm{~mm}$ diameter base, depending upon whether it was possible to place it on an undisturbed horizontal soil surface or not. A graduated cylindrical reservoir provides water. The base of the disc is covered with a nylon cloth of $20 \mu \mathrm{m}$ mesh. It is essential to maintain close hydraulic contact between the soil surface and the water source when measuring under tension. A sand layer ensures a good hydraulic contact between the disc and the soil. Excess contact sand outside the infiltrometer ring was swept away immediately after placement to avoid any horizontal wicks of sand lying across the soil surface. Measurements were made at two pressure heads $\left(h_{0}=-0.03\right.$ and $\left.-0.01 \mathrm{~m}\right)$. Cumulative infiltration $I(t)$ is recorded by noting the falling water level in the reservoir tower.

Disc infiltrometers have been widely used in situ during the last few decades to estimate the soil's hyraulic conductivity and its dependence on soil structure (Vauclin and Chopart, 1992; Lin and McInnes, 1995; Mohanty et al., 1994). In theory they may be of limited use or even prohibited in the field, because flow equations for disc infiltrometers all assume that the soil is homogeneous and isotropic and that the initial water content is uniform (Wooding, 1968; Haverkamp et al., 1994). In practice, water content gradients, soil bulk density, soil layering and extensive changes in the texture and structure of the soil all occur near the soil surface (White et al., 1992). The steady-state water flow analysis based on Wooding's equation (Wooding, 1968), which assumes homogeneity and isotropy, is normally used, but this is insufficient for heterogeneous soil profiles presenting a fine layering organization (Figure 2a-f). Several authors (Hussen and Warrick, 1993; Logsdon and Jaynes, 1993) have shown that it may lead to unrealistic results, including negative values for hydraulic conductivity. Conductivities, therefore, were obtained by analysing transient flow in order to overcome these difficulties; this meant shorter experiments and smaller sampled volumes of soil. In most soil study contexts these conditions agree better with assumptions of soil homogeneity and initial water content uniformity. Indeed, water content gradients and soil features usually occur along the vertical axis. Shorter experiments involve a reduction of the size of the soil sample in the vertical dimension.

A transient three-dimensional infiltration equation proposed by Haverkamp et al. (1994), and valid for time not approaching the steady state, has been used to obtain the unsaturated hydraulic conductivity $K\left(h_{0}\right)$, as described by Angulo Jaramillo et al. (2000) or Vandervaere et al. (2000a). The data were linearized by differentiating cumulative infiltration with respect to the square root of time (Vandervaere et al., 2000b). The early-time effect on water flow due to the presence of the initially dry contact sand was corrected (Vandervaere et al., 1997).

Tension-disc infiltrometry experiments at pressure heads of $h_{0}=-0.03 \mathrm{~m}(n=120)$ and $h_{0}=-0.01 \mathrm{~m}$ $(n=113)$ were carried out on previously described microplots. Both measurements are available for 83 microplots with the same SSCs. Each experiment lasted until the flow reached an estimated quasi-permanent regime (45 to $150 \mathrm{~min}$ ). Soil texture and initial and final volumetric water content were measured on samples. Furthermore, undisturbed soil cores were taken at 36 microplots in all SSC types except type BB to measure hydraulic conductivity at saturation $K_{\text {sat }}$ using a constant-head permeameter (Young, 1991), as it was seldom possible to use this device to measure saturation in situ (side water leakage).

\section{Statistical analysis}

Two complementary statistical methods that have been tested successfully for similar objectives in a different environment (Viville et al., 1986) were used to analyse the descriptive data set collected on 233 microplots and the hydrodynamical data set collected at 83 microplots, using SPSS software (SPSS, 1999):

- A hierarchical ascending classification (Jambu, 1978; Gordon, 1987) to identify a statistical a posteriori classification of microplots to be compared with the a priori expert SSC typology. This iterative method agglomerates the two microplots or groups of microplots that are the closest in the Euclidian $n$-dimensional space of the variables at each step, by minimizing the within-group inertia (or distance) and maximizing the 


\section{J.-P. MALET ET AL.}

between-groups inertia. Results are summarized using a linkage tree, showing the progressive agglomeration of individuals and giving the number of individuals $n$ and the inertia ratio $r$ (fraction of total inertia) associated with each group.

- A stepwise discriminant analysis (Lebart and Fénelon, 1973; Celeux and Nakache, 1994), to identify the most discriminant variables for these groups of plots. This iterative method determines the linear combination of variables (the discriminant function) that discriminates at best an a priori specified number of groups, by maximizing the ratio of the within-group and between-groups variances. At each step the variable that most improves the discrimination between groups is introduced into the combination, and the new combination is used to reclassify individuals. The final discriminant function can also be used to classify any new individual.

Decimal logarithmic transforms of hydraulic conductivities were used for all these treatments and the data was pre-processed: coding by introduction of a dummy variable for the qualitative variable [SCF] and standardization of the data.

\section{RESULTS AND DISCUSSION}

Validation of the typology: statistical classification of the microplots versus a priori expert soil surface characteristics typology

Table II presents the range of values for the 12 descriptors for each of the ten SSC types or sub-types. Variations between types are higher than the range obtained for each type for all descriptors.

Figure 3 presents the linkage tree for inertia rates higher than 0.005. Six groups are identified at the higher aggregation level, and they correspond very well to the 'expert-defined' SSC types; all or most of the microplots of the same SSC type (or even sub-type) are grouped within the same statistical group:

- All blocks and boulders (BB) microplots are in group 1011, with a clear distinction between sub-types BB1 and BB2 at the lower aggregation level (depending on the schistosity dipping).

- Most gravel crust (GC) microplots are within group 12, but a few GC microplots are grouped with SCL or SC microplots, as some descriptors ([ $\geq 2 \mathrm{~cm}],[0 \cdot 2-2 \mathrm{~cm}]$, [SIZ], [ROU] and [CR]) are identical for some of these microplots. The step before the distinction of the two groups GC1 and GC2 is due to the proportion of coarse fragments $\geq 2 \mathrm{~cm}$ and to the size of the coarsest.

Table II. Minimal and maximal values of descriptors for all SSC types and sub-types

\begin{tabular}{lccccccccccc}
\hline & BB1 & BB2 & UCL1 & UCL2 & SCL & SC & DC1 & DC2 & GC1 & GC2 & All \\
\hline$n^{\mathrm{a}}$ & 8 & 24 & 16 & 17 & 19 & 49 & 25 & 23 & 22 & 30 & 233 \\
{$[<0 \cdot 2 \mathrm{~cm}](\%)$} & 0 & 0 & 1 & 1 & $10-20$ & $65-80$ & $85-90$ & $90-95$ & $35-50$ & $15-25$ & $0-95$ \\
{$[0 \cdot 2-2 \mathrm{~cm}](\%)$} & 0 & 0 & $70-80$ & $70-80$ & $50-60$ & $15-40$ & $5-10$ & $5-10$ & $45-60$ & $35-50$ & $0-80$ \\
{$[\geq 2 \mathrm{~cm}](\%)$} & 100 & 100 & $20-30$ & $20-30$ & $10-30$ & $5-20$ & 1 & 1 & $10-20$ & $20-30$ & $1-100$ \\
{$[\mathrm{SCF}]^{\mathrm{b}}$} & Ang. & Ang. & Ang. & Ang. & Ang. & Sub. & Sub. & Sub. & Ang. & Ang. & \\
{$[\mathrm{SIZ}](\mathrm{mm})$} & $50-200$ & $50-200$ & $2-5$ & $2-5$ & $1-3$ & $0 \cdot 5-3$ & $0 \cdot 2-0 \cdot 3$ & $0 \cdot 05-0 \cdot 1$ & $2-2 \cdot 5$ & $3-5$ & $0 \cdot 05-200$ \\
{$[\mathrm{SF}](\%)$} & 100 & 100 & $2-5$ & $2-5$ & 100 & 100 & 100 & 100 & $80-90$ & $60-70$ & $2-100$ \\
{$[\mathrm{ROU}](\mathrm{mm})$} & $0 \cdot 5-1$ & $0 \cdot 5-1$ & $10-18$ & $10-25$ & $5-15$ & $2-10$ & $1-2$ & $0 \cdot 5-1$ & $3-12$ & $10-25$ & $0 \cdot 5-25$ \\
{$[\mathrm{CR}]\left(\mathrm{m} m \mathrm{~m}^{-2}\right)$} & $5-10$ & $5-10$ & $3-15$ & $3-15$ & $3-10$ & $2-5$ & $2-5$ & $2-5$ & $5-10$ & $1-3$ & $1-15$ \\
{$[\mathrm{WCR}](\mathrm{mm})$} & $0 \cdot 5-3$ & $0 \cdot 5-3$ & $2-12$ & $2-10$ & $1-4$ & $1-2$ & $5-12$ & $10-18$ & $2-3$ & $4-6$ & $1-18$ \\
{$[\mathrm{DCR}](\mathrm{mm})$} & $3-8$ & $3-8$ & $5-10$ & $5-15$ & $3-8$ & $13-22$ & $3-12$ & $12-30$ & $2-6$ & $6-8$ & $2-30$ \\
{$\left[\mathrm{ORI}\left(^{\circ}\right)\right.$} & $0-15$ & $15-90$ & $0-15$ & $15-90$ & $0-15$ & $0-15$ & $0-15$ & $0-15$ & $0-15$ & $0-15$ & $0-90$ \\
{$[\mathrm{CL}](\%)$} & 0 & 0 & $95-100$ & $95-100$ & $85-100$ & $15-25$ & $2-5$ & $1-2$ & $40-50$ & $70-80$ & $0-100$ \\
\hline
\end{tabular}

${ }^{\text {a }} n$ is the number of microplots.

${ }^{\mathrm{b}}$ Ang. is angular shape, Sub. is subangular shape. 


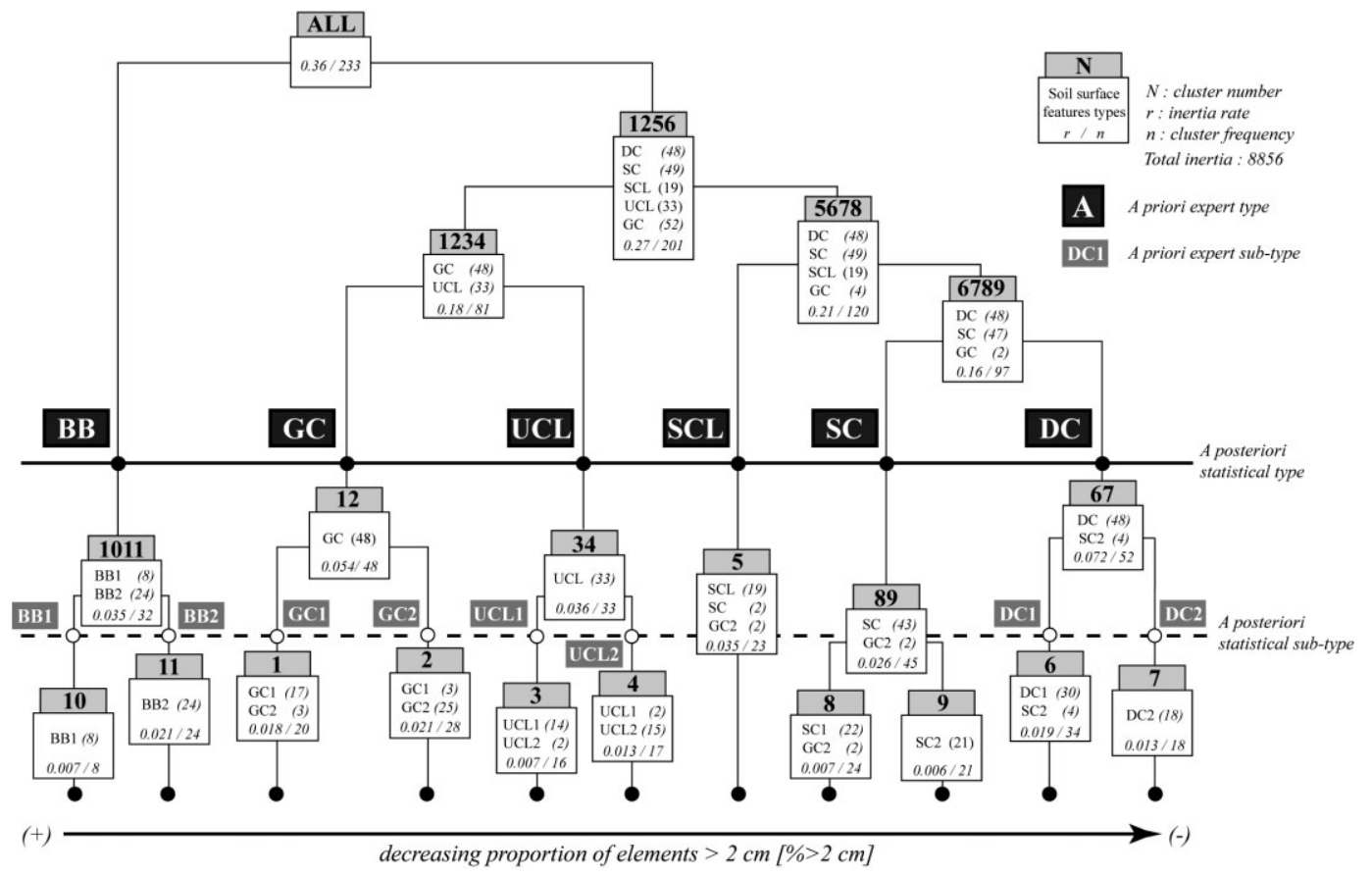

Figure 3. Linkage tree of the hierarchical ascending classification of the 233 microplots using 12 SSC descriptors

- All unsealed clast (UCL) microplots are within group 34, which represents 65\% of the individuals with a high proportion of clasts. Two sub-groups are well identified according to the clast orientation.

- All sealed clast (SCL) microplots are within group 5, which represents $35 \%$ of the individuals with a high proportion of clasts.

- Most structural crust (SC) microplots are within group 89, but a few SC plots are grouped with SCL or SC microplots, which are very neighbouring types. Two sub-groups, not well recognised in the a priori expert typology, are well identified according to the proportion of elements $0 \cdot 2-2 \mathrm{~cm}$, the size of the coarser elements and the roughness grade.

- All depositional crusts (DC) microplots are within group 67, with a very good distinction in two sub-groups according to the proportion of finer material $(<0 \cdot 2 \mathrm{~cm})$ and the roughness grade.

As a whole, $96 \%$ of the 233 plots are well classified in their SSC types. The remaining $4 \%$ represent some structural or depositional crust and sealed clasts.

Thus, this statistical classification reveals a differentiation clearly dependent on SSC, by three opposing main categories of SSC types: marl blocks and boulders, 'stony' types (gravel crusts, unsealed clasts), and the finer types (sealed clasts, structural and depositional crusts). The validity of the a priori expert SSC typology (in six types and ten sub-types) is confirmed when microplots are statistically classified a posteriori (into six types and ten sub-types) using the detailed infiltration-oriented SSC descriptions.

\section{Surface soil characteristics typology and hydraulic conductivities}

The objective is to ascertain whether the differences in SSCs lead to significant differences in surface hydraulic conductivities. Measured vertical hydraulic conductivities present a large dispersion up to three orders of magnitude at each negative pressure head: from $5.8 \times 10^{-7}$ to $1.8 \times 10^{-5} \mathrm{~m} \mathrm{~s}^{-1}$ at saturation, from $5.0 \times 10^{-7}$ to $1.4 \times 10^{-5} \mathrm{~m} \mathrm{~s}^{-1}$ at pressure head of $-0.01 \mathrm{~m}$ and from $8.3 \times 10^{-8}$ to $1.7 \times 10^{-5} \mathrm{~m} \mathrm{~s}^{-1}$ at pressure head of $-0.03 \mathrm{~m}$. These results are consistent with those obtained on black marl slopes by several authors (Malherbe, 1995; Grésillon, 1997; Van Asch and Buma, 1997) and show that hydraulic conductivities could be higher than the usual values given for this kind of texture. 

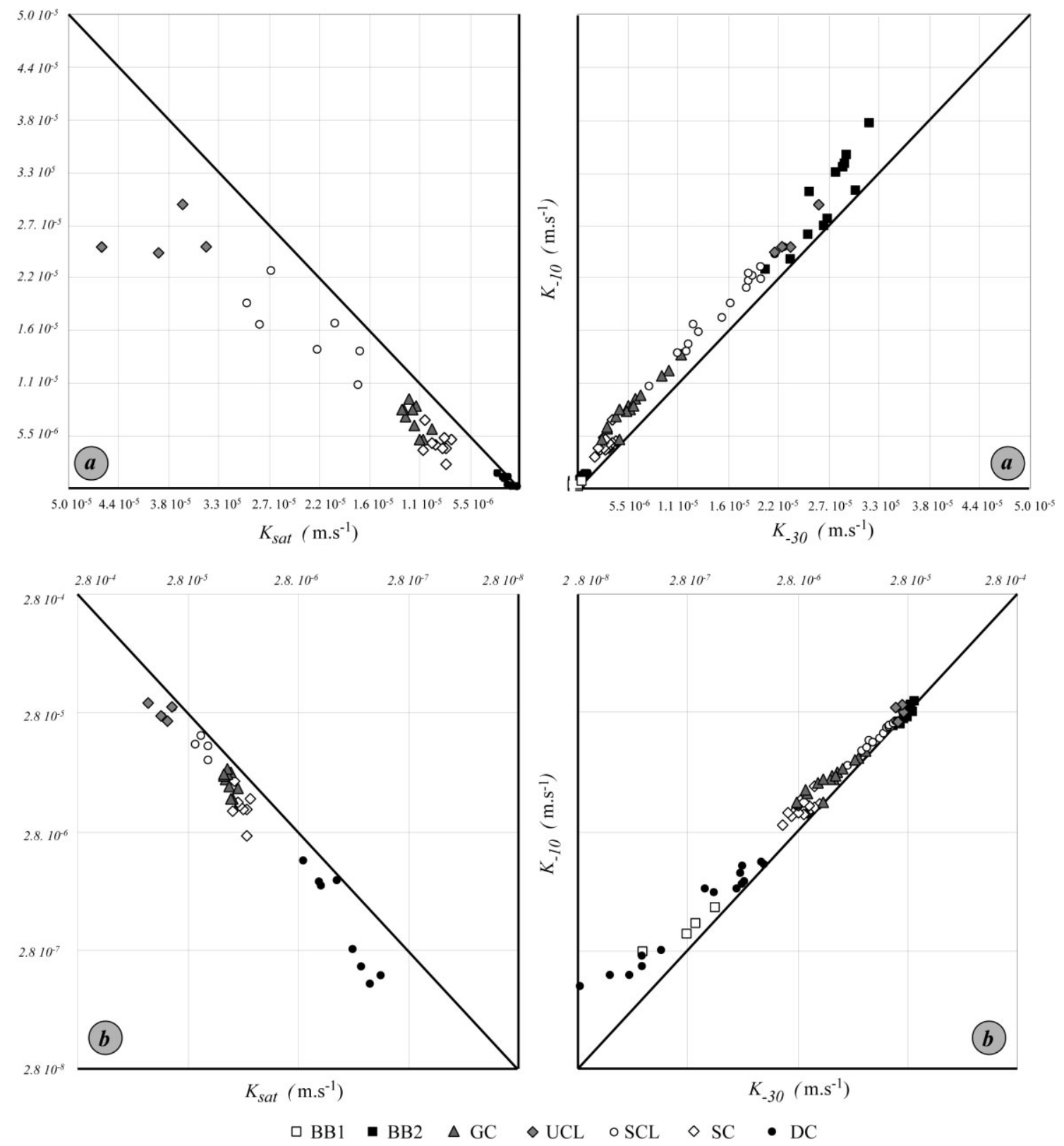

Figure 4. Representation of the hydrodynamic triplets $\left(K_{\text {sat }}, K_{-0.01}\right.$ and $\left.K_{-0.03}\right)$ by 'expert' SSC types in a linear (a) and $\log -\log$ (b) scale

Figure 4 shows the distribution of the values of $K_{\text {sat }}, K_{-0.01}$ and $K_{-0.03}$ by SSC type. The lowest values are associated with DC and the highest with BB2. BB1 and BB2 are clearly distinguished and show the influence of the schistosity dipping. The position relative to the bisector shows the more or less rapid fall in the hydraulic conductivity curve from saturation, which varies according to SSC type, as expected. Decreases are larger between saturation and $-0.01 \mathrm{~m}$ than between -0.01 and $-0.03 \mathrm{~m}$, as a higher proportion of larger pores are active at $-0.01 \mathrm{~m}$ than at $-0.03 \mathrm{~m}$, given the texture of the SSC. They are also larger for both clast types (UCL, SCL) than for crust types (GC, SC); this is not surprising, since the porosity is higher and more heterogeneous than in the crusts. The decrease is also high for the DC type, due to the influence of desiccation cracks, in spite of a homogeneous very fine porosity. Table III summarizes the mean values 


\section{INFLUENCE OF SOIL SURFACE CHARACTERISTICS ON INFILTRATION}

and standard deviations for each type. Geometric mean values are given, as hydraulic conductivities usually follow lognormal distributions (Warrick and Nielsen, 1980; Vauclin, 1983).

Differences in hydraulic conductivities between individuals are not random: the variance homogeneity test (Sheffé-Box log-anova test; Wonnacott and Wonnacott, 1990) for hydraulic conductivities $K_{\text {sat }}, K_{-0.01}$ and $K_{-0.03}$ enables us to reject the null hypothesis. A hierarchical ascending classification using hydraulic conductivity data only was therefore performed on two sets of plots:

- the 83 plots, for which both $K_{-0.01}$ and $K_{-0.03}$ were measured using in situ tension-disc infiltrometry;

- among them, the 36 plots for which $K_{\text {sat }}$ was also measured in the laboratory using undisturbed soil cores; this subset includes no BB-type plots.

Figure 5 presents the linkage trees for inertia rates higher than 0.005 . Figure $5 \mathrm{a}$ shows the progressive agglomeration of the 83 plots into groups, using only two conductivity values. Six groups are identified at the higher aggregation levels, which again correspond rather well with the 'expert' SSC types:

- group 123 represents the less permeable microplots, which belong to two SSC types, viz. all depositional crust (DC) microplots and all blocks with more or less horizontal schistosity (BB1);

- group 4 contains all structural crust (ST) microplots (with one exception), together with a few gravel crust (GC) microplots;

- group 56 contains most of the gravel crust (GC) microplots, together with one structural crust (SC) microplot;

- group 7 contains all sealed clast (SCL) microplots, together with one gravel crust (GC) microplot;

- group 89 contains a combination of two SSC types, viz. all unsealed clast (UCL) microplots and half of the blocks with oblique or vertical schistosity (BB2);

- group 10 contains the other half of the BB2 microplots, whose important vertical macroporosity leads to the highest vertical conductivities.

Some 93\% of the microplots are well classified within their SSC types. It is difficult, therefore, to distinguish DC and BB1 microplots, as well as UCL and BB2 microplots, at both extremes of the conductivity range using only two points of the conductivity curve. According to this result, the BB group, which occupies a limited area of the earthflow, should be split into two types, BB1 and BB2, for infiltration. Although other types are already well discriminated, there is some uncertainty in the classification of GC microplots, whose behaviour appears rather similar to that of the neighbouring SC or SCL type. The discrimination of GC microplots is improved by introducing a third point on the conductivity curve, as shown by the results obtained on the subset of 36 microplots for which $K_{0}$ data exist (Figure $5 \mathrm{~b}$ ). This discrimination depends on high macroporosity differences between each SSC type. In that case, all microplots (except one SC microplot) are well classified within their SSC types and sub-types. The main finding, therefore, is that the SSC types lead to significant differences in surface hydraulic conductivities.

\section{Identification of the most discriminant soil surface characteristics variables}

There is a very good correspondence between hydrodynamic groups and SSC types, so a stepwise discriminant analysis was tested on the 233 microplots in order to identify the combination of description variables (discriminant function) that best discriminates the six SSC types and ten SSC sub-types defined by the $a$ priori 'expert opinion' and validated by statistics. Therefore, a number of the ten groups has been imposed to the discriminant analysis.

Figure 6 and Table IV show the results of the best classification obtained. If the ten statistical groups corresponded perfectly to the ten a priori imposed SSC sub-types, all plots would appear on the matrix diagonal (this is the case for $86 \%$ of the 233 microplots). Considering the six SSC types, $92 \%$ of the microplots are well classified in their types, with the few remaining microplots being classified in neighbouring types. 
J.-P. MALET ET AL.

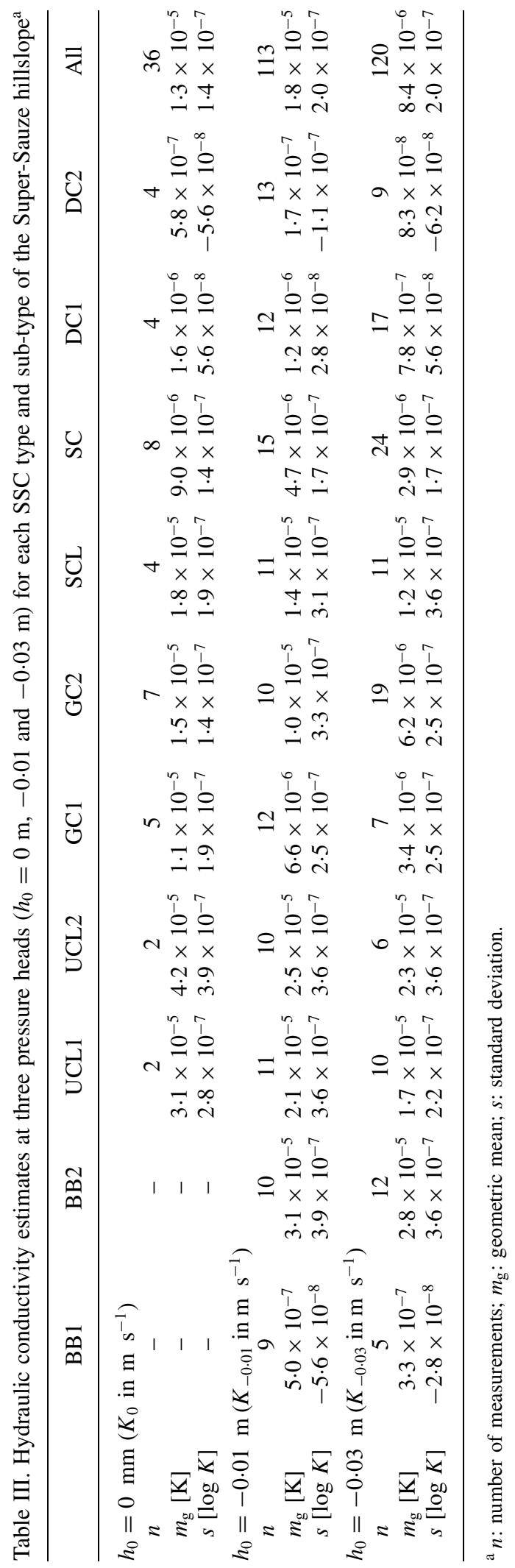



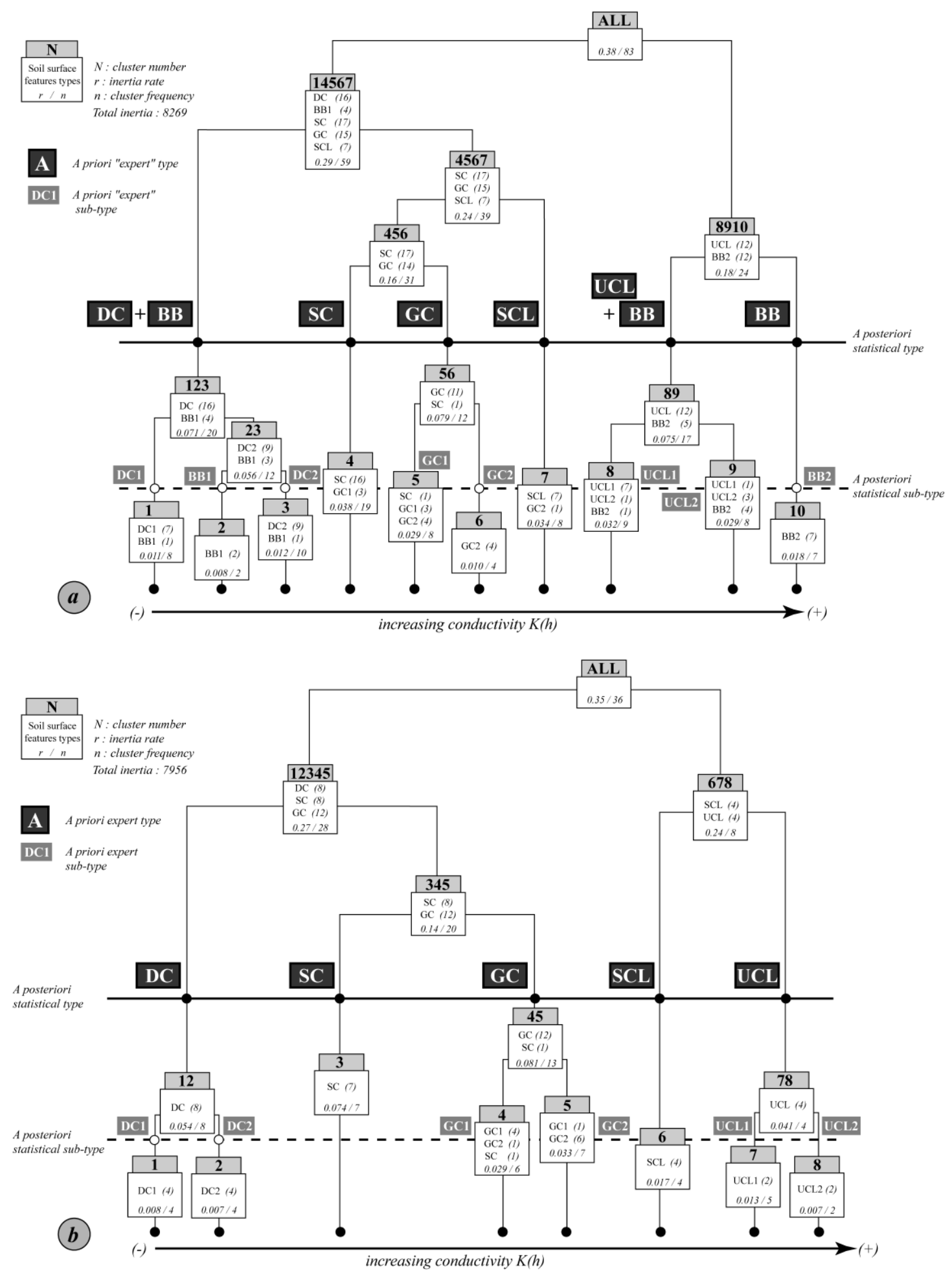

Figure 5. Linkage tree of the hierarchical ascending classification on the conductivity characteristics of (a) 83 microplots $\left(K_{-0.01}\right.$, $\left.K_{-0.03}\right)$ and (b) of 36 microplots $\left(K_{\text {sat }}, K_{-0.01}, K_{-0.03}\right)$ 


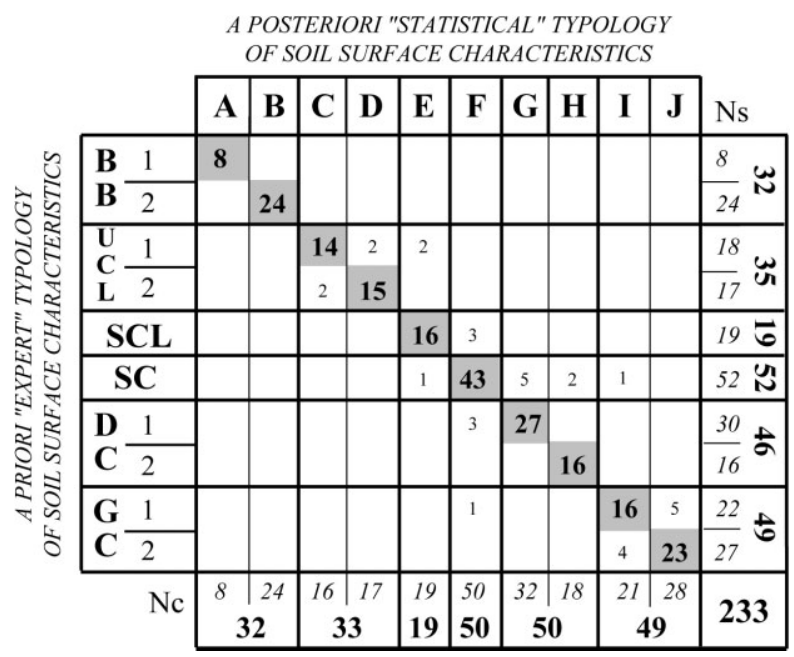

Figure 6. Stepwise discriminant analysis on the SSC descriptors variables: a posteriori 'statistical' descriptive classification versus $a$ priori expert classification by type and sub-type of 233 microplots

Table IV. Stepwise discriminant analysis using SSC descriptors: discriminant variables (DV) and percentage of well-classified microplots for the seven first seven steps and the final step ${ }^{\mathrm{a}}$

\begin{tabular}{|c|c|c|c|c|c|c|}
\hline \multirow[t]{3}{*}{ Step } & \multicolumn{6}{|c|}{ All 12 SSC descriptors, 233 microplots } \\
\hline & \multicolumn{3}{|c|}{ All surface types } & \multicolumn{3}{|c|}{ Cross-validation } \\
\hline & DV & $a \%$ & $b \%$ & DV & $a \%$ & $b \%$ \\
\hline 1 & {$[<0 \cdot 2 \mathrm{~cm}]$} & 14 & 15 & {$[<0.2 \mathrm{~cm}]$} & 12 & 13 \\
\hline 2 & {$[\mathrm{SF}]$} & 24 & 27 & {$[\mathrm{SF}]$} & 21 & 23 \\
\hline 3 & {$[\geq 2 \mathrm{~cm}]$} & 32 & 35 & {$[\geq 2 \mathrm{~cm}]$} & 28 & 32 \\
\hline 4 & {$[\overline{\mathrm{C}} \mathrm{R}]$} & 38 & 43 & {$[\overline{\mathrm{C}} \mathrm{R}]$} & 36 & 41 \\
\hline 5 & [ORI] & 45 & 51 & [ORI] & 43 & 48 \\
\hline 6 & [ROU] & 51 & & [ROU] & 49 & 54 \\
\hline 7 & [SIZ] & 57 & 62 & [SIZ] & 54 & 59 \\
\hline Final & $12 \mathrm{DV}$ & 86 & 92 & $12 \mathrm{DV}$ & 79 & 86 \\
\hline
\end{tabular}

a \%: percentage of well classified microplots; $a$ : by SSC sub-type; $b$ : by SSC type.

The discrimination between 'fine' SSC types (SCL, SC, DC) and sub-types is rather good, and it is excellent between 'coarse' SSC types (BB, UCL, GC) and sub-types. The microplots chosen seem representative of their SSC type and sub-type, as there is no systematically poor sample classification. The samples of types $\mathrm{BB}, \mathrm{UCL}$ and GC are very well classified in their 'expert' SSC type and the types differ significantly from each other. The samples of the a priori sub-types BB1, BB2, DC1, DC2 are also well classified statistically (no classification errors). Finally, the very few confusions relate to genetically closer groups.

This result has been obtained essentially after seven steps: a combination of seven descriptors allows one to classify properly $57 \%$ and $62 \%$ of the microplots into respectively SSC sub-types and SSC types. Only limited improvement is obtained by more steps. Table IV gives the order of appearance and combination of variables that best distinguish the ten sub-types:

- at step 1 , the percentage of fine material $[<0 \cdot 2 \mathrm{~cm}]$ discriminates the microplots with coarse fragments from those more sensitive to sealing and crusting (discrimination of more than $70 \%$ of the SC and DC microplots);

- at step 2, the proportion of the area covered by sealed fragments $[\mathrm{SF}]$ distinguishes between crusted and non-crusted SSC types (BB, UCL, SCL and DC microplots); 
- at step 3, the proportion of coarse fragments $[2-2 \mathrm{~cm}]$ distinguishes between stony and fine SSC types (GC, UCL, SC, DC);

- at step 4, the density of the cracks [CR] improves the internal classification of the GC type;

- at step 5, the clasts dipping [ORI] improves the internal classification of BB and UCL types;

- at step 6 , the roughness grade [ROU] improves the internal classification of crusted types (GC, DC);

- and finally, step 7 introduces the size of the coarser clasts [SIZ], which heightens the distinction between UCL and GC types.

As expected, stepwise discriminant analyses gives about the same results as the ascending hierarchical classification. The improvement in discrimination seems very progressive. Given the great heterogeneity of SSCs, a majority of descriptors appears necessary to discriminate the types and sub-types. Nevertheless, some SSC types (BB, UCL, DC) are distinguished at the outset because of their very specific morphology, which can only be described by a combination of two descriptors. Some $80 \%$ of the sample was cross-validated using a discriminant analysis and the discrimination functions of the remaining $20 \%$ were tested, as suggested by Romeder (1973). Partition of the data sets was carried out using a random cluster sampling. Very similar percentages of well-classified microplots in this remaining $20 \%$ shows that roughly the same percentages were obtained (Table IV). The well-classified microplot percentages that occur only in this $20 \%$ population are identical with well-classified microplot percentages classified in the whole population. This shows the relevance of the choice of adapted descriptors for the discrimination of such particular SSC types.

\section{Towards hydraulic response units}

Based on the results, Figure 7 presents the 'envelope curves' of measured hydraulic conductivity near saturation. The SSC types show significant differences in hydraulic conductivity. Each SSC type shows significant variations; this is usual for conductivity values (Warrick and Nielsen, 1980; Ambroise and Viville, 1986; Kutílek and Nielsen, 1994). For the three pressure heads, the order of the SSC types remains as follows:

- The highest values $\left(>1.4 \times 10^{-5} \mathrm{~m} \mathrm{~s}^{-1}\right)$ are associated with marl blocks with a vertical or oblique schistosity (BB2) and with unsealed clasts (UCL). The decrease in hydraulic conductivity between saturation and $-0.01 \mathrm{~m}$ of the pressure head is also higher for these SSC types than for the others, due to their significant vertical macroporosity. Visibly, they lead to higher infiltration rates than usual for this kind of marly material.

- The lowest values $\left(<2.8 \times 10^{-6} \mathrm{~m} \mathrm{~s}^{-1}\right)$ are associated with the depositional crusts (DC) and marl blocks with a horizontal schistosity (BB1), because of their very limited vertical macroporosity.

- Sealed clasts (SCL), gravel crusts (GC) and structural crusts (SC) show intermediate hydraulic conductivity values $\left(2.8 \times 10^{-6}\right.$ to $\left.1.4 \times 10^{-5} \mathrm{~m} \mathrm{~s}^{-1}\right)$ : as the proportion of matrix increases, the surface hydraulic conductivity decreases.

Standard deviations for structural (SC) or depositional (DC) crusts are relatively small, but the values are similar to the mean hydraulic conductivities for all other types (Table III). This may be explained by a higher heterogeneity in topsoil texture for these other types. For crusted types (GC, SC, DC), except sub-type DC2, the limited differences in conductivity between -0.01 and $-0.03 \mathrm{~m}$ could indicate that the same porous system is active at this low suction range. The more rapid decrease in conductivity between -0.01 and $-0.03 \mathrm{~m}$ for sub-type DC2 is due to the dessication cracks that were observed.

\section{CONCLUSION}

The object of this research was to investigate the influence of SSCs on hydraulic conductivity in black marls. We expected SSCs to explain spatial variations in the infiltration processes observed under natural rainfall in this relatively undifferentiated material. This approach aimed to select relevant variables to build an oriented SSC typology to assess the range of infiltration rates at the soil surface. 


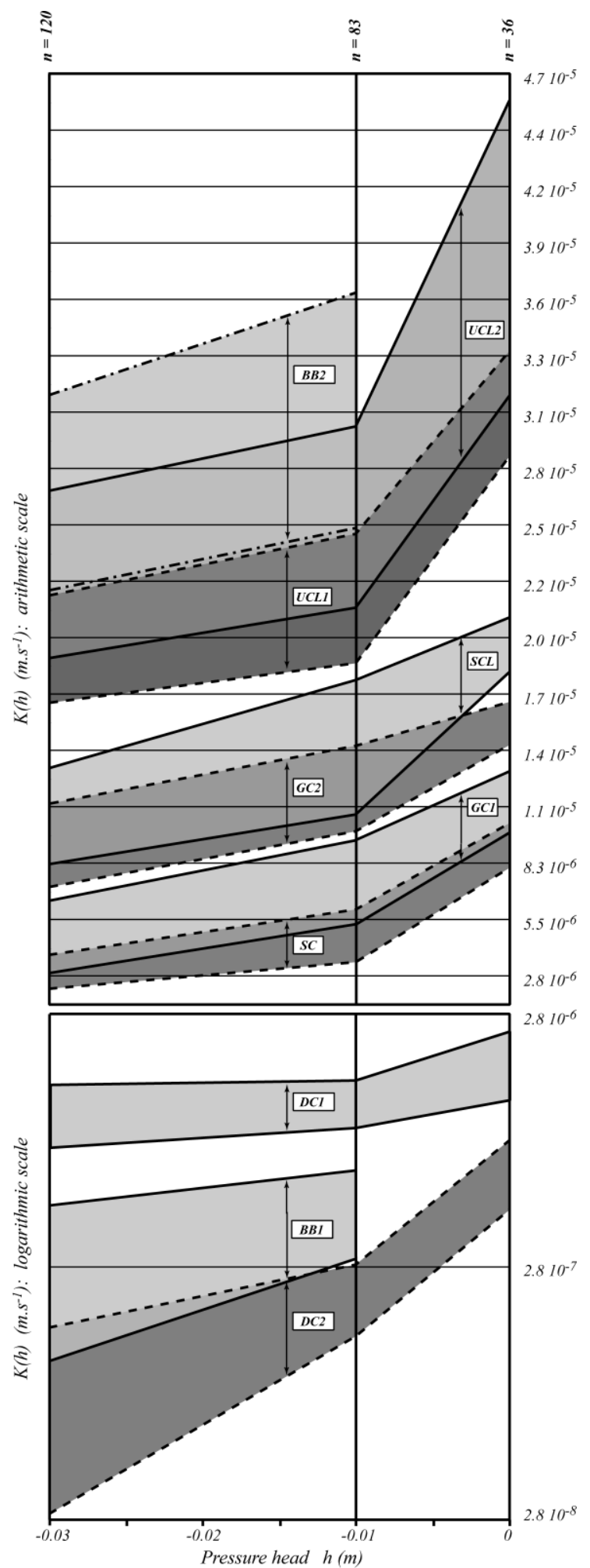

Figure 7. Envelopes of measured hydraulic conductivity curves (from saturation to $-0.03 \mathrm{~m}$ ) for all SSC types and sub-types 
The first stage involved validating the SSC typology by classifying the descriptive data of SSC obtained from a large sample of 233 microplots selected over the whole earthflow. The infiltrometry measurements at saturation and for low suctions show the variability of the hydraulic conductivity: at saturation, the range of value is $5.8 \times 10^{-7}$ to $1.1 \times 10^{-5} \mathrm{~m} \mathrm{~s}^{-1}$; at pressure head of $-0.03 \mathrm{~m}$, the range is $8.3 \times 10^{-8}$ to $1.2 \times$ $10^{-5} \mathrm{~m} \mathrm{~s}^{-1}$. Variability is really lower within a group of microplots from the same type of SSC than within the whole sample. Moreover, the order between groups remained the same whatever the pressure head. These results indicate that SSCs are key factors in explaining the variability of the hydraulic conductivity.

If 12 variables were selected as descriptors of SSCs, the stepwise discriminant analysis of the whole set of descriptive data indicated that a combination of only seven descriptors enabled us to classify about $60 \%$ of the microplots satisfactorily. As expected, five of these descriptors relate to soil texture, crust and roughness; the other two relate to the size and the orientation of the clasts and are specific to black marls.

SSC spatial variations and dynamics may lead to significant differences in infiltration properties. The descriptor approach adds very useful information for simplifying the measurement strategy. It also seems to be very useful to discriminate, and therefore to map, soil surface units with significantly different hydrodynamical behaviours.

However, this approach requires the descriptors to be adapted to take account of some specificities of the material that partly control the open porous system or the microrelief; the influence of the clasts indicated here should probably be taken into account for all types of marl, the weathering of which produces clasts.

These local results lead us to question the infiltration conditions in wider units that are distinguished by the juxtaposition and interlocking of different types of SSC zone. The distribution of possible pounds and connectivities on the runoff course may lead to high differences in infiltration or runoff responses; this is possibly due to the structure on this scale (presence, extension and relative position of SSC types). This may partly explain the differences in the distribution of ground water levels within a landslide body (preferential infiltration flowpaths) and must be taken into account in distributed hydrological models.

\section{ACKNOWLEDGEMENTS}

This study was funded by RIDES 'Ruissellement, Infiltration et Dynamique des États de Surface' (Runoff, Infiltration and Dynamics of Soil Surface Characteristics), a joint PNRH (Programme National de Recherches en Hydrologie) and PNSE (Programme National de Recherches Sols et Érosion) programme. Contribution INSU No. 314. Contribution EOST No. 2002.003-UMR7516. We thank P. Gay, M. Marquès, A. Puissant, A. Remaítre and A. Ritzenthaler for participating in field measurements. Very special thanks are due to Miss Margaret Nelson for the reviewing of the English version of the manuscript.

\section{REFERENCES}

Abrahams AD, Parsons AJ. 1991. Relation between infiltration and stone cover on a semi-arid hillslope in Southern Arizona. Journal of Hydrology 122: 49-59.

Ambroise B, Viville D. 1986. Spatial variability of textural and hydrodynamic properties in a soil unit of the Ringelbach study catchment, Vosges (France). Zeitschrift für Geomorphology Supplementband 58: 21-34.

Antoine P, Giraud A, Meunier M, van Asch TWJ. 1995. Geological and geotechnical properties of the "Terres Noires" in the southeastern France: weathering, erosion, solid transport and instability. Engineering Geology 40: 223-234.

Angulo-Jaramillo R, Vandervaere J-P, Roulier S, Thony J-L, Gaudet JP, Vauclin M. 2000. Field measurement of soil surface hydraulic properties by disc and ring infiltrometers: a review and recent developments. Soil and Tillage Research 55: 1-29.

Auzet AV. 2000. Ruissellement, érosion et conditions de surface des sols á l'échelle de versants et petits bassins versants. Memoire d'Habilitation á Diriger des Recherches. Université Louis Pasteur: Strasbourg I; 79pp.

Auzet A-V, Boiffin J, Ludwig B. 1995. Concentrated flow erosion in cultivated catchments: influence of soil surface state. Earth Surface Processes and Landforms 20: 759-767.

Bradford JM, Ferris JE, Remley PA. 1987. Interrill soil erosion processes: I. Effects of surface sealing on infiltration, runoff and splash development. Soil Science Society of America Journal 51: 1566-1571.

Casenave A, Valentin C. 1989. Les États de Surface de la Zone Sahélienne. Influence sur l'Infiltration. Orstom.

Celeux G, Nakache J-P. 1994. Analyse Discriminante sur Variables Qualitatives et Quantitatives. Polytechnica: Paris.

Descroix L, Olivry J-C. 2002. Spatial and temporal factors of erosion by water of black marls in the badlands of the French southern Alps. Hydrological Sciences 47: 227-242.

Flageollet J-C, Malet J-P, Maquaire O. 2000. The 3-D structure of the Super-Sauze earthflow: a first stage toward modelling its behaviour. Physics and Chemistry of the Earth Part B 25(9): 785-791. 


\section{J.-P. MALET ET AL.}

Gordon AD. 1987. A review of hierarchical classification. Journal of Research in Statistics 150: 119-137.

Grésillon J-P. 1997. Rétention en eau, infiltrabilité des sols et compréhension des processus hydrologiques. In Actes de Colloque Draix-Le Brusquet-Digne: Les bassins versants expérimentaux de Draix, laboratoire d'étude de l'érosion en montagne, vol. 1. Cemagref: Grenoble; 303-312.

Haverkamp R, Ross PJ, Smettem KRJ, Parlange J-Y. 1994. Three dimensional analysis of infiltration from the disc infiltrometer. Part 2. Physically based infiltration equation. Water Resources Research 30: 2931-2935.

Hussen AA, Warrick AW. 1993. Alternative analysis of hydraulic data from the disc tension infiltrometers. Water Resources Research 29: $4103-4108$.

Jambu M. 1978. Classification Automatique pour l'Analyse des Données. 1. Méthodes et Algorithmes. Dunod: Paris.

Jetten V, Boiffin J, De Roo A. 1996. Defining monitoring strategies for runoff and erosion studies in agricultural catchments: a simulation approach. European Journal of Soil Science 47: 579-592.

Kutílek M, Nielsen DR. 1994. Soil Hydrology. Catena-Verlag: Cremlingen.

Lebart L, Fénelon J-P. 1973. Statistique et Informatique Appliquée. Dunod: Paris.

Le Bissonnais Y. 1998. Crusting, runoff and sheet erosion on silty loamy soils at various scales and upscaling from $\mathrm{m}^{2}$ to small catchments. Soil and Tillage Research 46: 69-80.

Léonard J, Andrieux P. 1998. Infiltration characteristics of soils in Mediterranean vineyards in southern France. Catena 32: $209-223$.

Lin HS, McInnes KJ. 1995. Water flow in clay soil beneath a tension infiltrometer. Soil Science 159(6): 375-382.

Logsdon SD, Jaynes DB. 1993. Methodology for determining hydraulic conductivity with tension infiltrometers. Soil Science Society of America Journal 57: 1426-1431.

Malet J-P, Maquaire O, Calais E. 2002a. The use of global positioning system for the continuous monitoring of landslides. Application to the Super-Sauze earthflow (Alpes-de-Haute-Provence, France). Geomorphology 43: 33-54.

Malet J-P, Van Asch TWJ, Van Beek LH, Maquaire O. 2002b. Distributed hydrological modelling of the Super-Sauze earthflow (south east France): implementation of the Starwars model. In Geomorphology, from Expert Opinion to Modelling, Delahaye D, Levoy F, Maquaire O (eds). Cerg Edition: Strasbourg; 65-72.

Malherbe B. 1995. Caractérisation hydrodynamique des sols d'un bassin versant dénudé de végétation: le Laval (Draix, Alpes-de-HauteProvence, France). Internal Report LTHE.

Maquaire O, Flageollet J-C, Malet J-P, Schmutz M, Weber D, Klotz S, Albouy Y, Descloîtres M, Dietrich M, Guérin R, Schott J-J. 2001. Une approche multidisciplinaire pour la connaissance d'un glissement-coulée dans les marnes noires (Super-Sauze, Alpes-deHaute-Provence, France). Revue Française de Géotechnique 95-96: 15-31.

Mohanty BP, Ankeny MD, Horton R, Kanwar RS. 1994. Spatial analysis of hydraulic conductivity measured using disc infiltrometers. Water Resources Research 30: 2489-2498.

Moussa R, Voltz M, Andrieux P. 2002. Effects of the spatial organization of agricultural management on the hydrological behaviour of a farmed catchment during flood events. Hydrological Processes 16: 393-412.

Perroux KM, White I. 1988. Design for disc permeameters. Soil Science Society of America Journal 52: 1205-1215.

Poesen JW, Ingelmo-Sanchez F, Mücher H. 1990. The hydrological response of soil surfaces to rainfall as affected by cover, position of rock fragments in the top layer. Earth Surface Processes and Landforms 15: 653-671.

Romeder J-M. 1973. Méthodes et Programme d'Analyse Discriminante. Dunod: Paris.

Schmutz M, Albouy Y, Guérin R, Maquaire O, Vassal J, Schott J-J, Descloîtres M. 2000. Joint electrical and time domain electromagnetism (TDEM) data inversion applied to the Super-Sauze earthflow (France). Surveys in Geophysics 21(4): 371-390.

Smettem KRJ, Clothier BE. 1989. Measuring unsaturated sorptivity and hydraulic conductivity using multiple disc permeameters. Journal of Soil Science 40: 563-568.

SPSS. 1999. SPPS - User Manual. A Guide to use SPSS 8.0 on Windows 95/NT. Department of Computing and Communications, Memorial University of Newfoundland: St John's, Newfoundland, Canada.

Van Asch TWJ, Buma J. 1997. Modelling groundwater fluctuations and the frequency of movement of a landslide in the "Terres-Noires" region of Barcelonnette (France). Earth Surface Processes and Landforms 22: 131-141.

Vandervaere J-P, Peugeot C, Vauclin M, Angulo-Jaramillo R, Lebel T. 1997. Estimating hydraulic conductivity of crusted soils using disc infiltrometers and minitensiometers. Journal of Hydrology 188-189: 203-223.

Vandervaere J-P, Vauclin M, Elrick DE. 2000a. Transient flow from tension infiltrometers. Part 2. Four methods to determine sorptivity and conductivity. Soil Science Society of America Journal 64: 1272-1284.

Vandervaere J-P, Vauclin M, Elrick DE. 2000b. Transient flow from tension infiltrometers. Part 1. The two-parameter equation. Soil Science Society of America Journal 64: 1263-1272.

Vauclin M. 1983. Méthodes d'étude de la variabilité spatiales des propriétés d'un sol. Les Colloques de l'Institut National de la Recherche Agronomique 15-6: 9-43.

Vauclin M, Chopart J-L. 1992. L'infiltrométrie multi-disques pour la détermination in situ des caractéristiques hydrodynamiques de la surface d'un sol gravillonnaire de Côte d'Ivoire. Agronomie Tropicale 46: 259-271.

Viville D, Ambroise B, Korosec B. 1986. Variabilité spatiale des propriétés texturales et hydrodynamiques des sols dans le bassin-versant du Ringelbach (Vosges, France). Zeitschrift für Geomorphology Supplementband 60: 21-40.

Wainwright J. 1996. Hillslope response to extreme storm-events: the example of the Vaison la Romaine event. In Advances in Hillslope Processes, Anderson MG, Brooks SM (eds). 997-1026.

Warrick AW, Nielsen DR. 1980. Spatial variability of soil physical properties in the field. In Applications of Soil Physics, Hillel D (ed). Academic Press: 319-344.

White I, Sully MJ, Perroux KM. 1992. Measurement of surface-soil hydraulic properties: disc permeameters, tension infiltrometers and other techniques. In Advances in Measurement of Soil Physical Properties: Bringing Theory into Practice. Soil Science Society of America, Special Publication. Madison, Wisconsin, USA; 69-103.

Wooding RA. 1968. Steady infiltration from a shallow circular pond. Water Resources Research 4: 1259-1273.

Wonnacott TH, Wonnacott RJ. 1990. Introductory Statistics for Business and Economics. J. Wiley \& Sons: New York.

Young EG. 1991. Infiltration measurements. A review. Hydrological Processes 5: 309-320. 